\title{
Sustainable clean-up technologies for soils contaminated with multiple pollutants: Plant-microbe-pollutant and climate nexus
}

\author{
Vishal Tripathi ${ }^{\mathrm{a}}$, Leonardo F. Fraceto ${ }^{\mathrm{b}}$, P.C. Abhilash ${ }^{\mathrm{a}, *}$ \\ a Institute of Environment \& Sustainable Development, Banaras Hindu University, Varanasi, India \\ ${ }^{\mathrm{b}}$ Department of Environmental Engineering, São Paulo State University - UNESP, Sorocaba, SP, Brazil
}

\section{A R T I C L E I N F O}

\section{Article history:}

Received 12 February 2015

Received in revised form 10 April 2015

Accepted 23 May 2015

Available online 5 June 2015

\section{Keywords:}

Sustainable remediation

Contaminated soils

Multiple pollutants

Phytoremediation

Plant-microbe-pollutant interactions

Carbon neutral

Climate change

Sustainability indicators

\begin{abstract}
A B S T R A C T
Soil is a vital life supporting system of the Planet Earth. However, it has been estimated that around 25\% the global soils are highly degraded and $44 \%$ are moderately degraded mainly due to the pollution of metals and metalloids, persistent organic pollutants, pesticides, radionuclides etc. Additionally, the pollution due to new and emerging pollutants such as antibiotics, disinfectants, flame retardants, nanoparticles etc pose an additional threat to the homeostasis of the soil system. Therefore, sustainable management of contaminated soils are essential for maintaining the ecosystem services. Though chemical and physical methods are widely pursued for the remediation of contaminated soils, phytotechnolgies (plant-based clean-up technologies) are outweighed and often preferred as a clean and carbon-neutral solution for the remediation and sustainable management of the contaminated soils. Apart from that, plant-based clean-up also provide phytoprodcuts such as biomass, biofuels and other industrially important chemicals for bio-based entrepreneurial activities during remediation. However, phytoremediation does not give desired results in soil contaminated with mixed/multiple pollutants. Furthermore, it is unclear that how changing climate will affect the plant-microbe interactions and pollutants behaviour in the soil system. Moreover, there is only limited information available on the plant-microbe-pollutants nexus under changing climate. Therefore, the present work is aimed to (i) address the difficulties in remediation of soils contaminated with multiple pollutants (ii) delineate the plant-microbe-pollutant and climate nexus and (iii) identify the key sustainability indicators for evaluating the remediated system.
\end{abstract}

()2015 Elsevier B.V. All rights reserved.

\section{Soil remediation: the need of the hour}

The past few decades have seen an upsurge in the anthropogenic activities leading to the unprecedented pollution of the biosphere. Rapid industrialization, urbanization and intensive agricultural activities have resulted in the release of large amount of heavy metals, pesticides, radionuclides, petroleum hydrocarbons etc. Moreover, the advancement in pharmaceutical, biomedical, electronics and materials science etc have lead to the pollution of the ecosystems with new and emerging pollutants such as antibiotics, antiepileptics, analgesics, anti-inflammatories, lipid regulators, betablockers, diuretics, contrast media, cosmetics, psycho-stimulants, disinfectant, antidepressants, plasticisers and phthalates, wood preservatives, paint additives, nanoparticles etc. (Table 1.) (Abhilash and Singh, 2009; Jamil et al., 2009a,b;

\footnotetext{
* Corresponding author at: Institute of Environment \& Sustainable Development, Banaras Hindu University, Varanasi 221005, India. Tel.: +919415644280.

E-mail address: pca.iesd@bhu.ac.in (P.C. Abhilash).
}

Srivastava et al., 2011; Vijgen et al., 2011; Srivastava et al., 2013; de Oliveira et al., 2014; Bakshi et al., 2014; Dubey et al., 2014; Tripathi el al., 2014a,b, 2015; Gavrilescu et al., 2015). Most of these contaminants are resistant to chemical, pholytic, hydrolytic and biological means of degradation so that they would persist in the receiving system for a very long period of time. Since soil is a major sink of these pollutants, the contamination of the soil system poses a serious threat to human existence as it provides food, fibre, fodder and other basic necessities to human beings. Moreover, it also support biodiversity and regulate all biogeochemical cycling in nature. Unfortunately, around $25 \%$ of the global soils are highly degraded and $44 \%$ are moderately degraded (FAO, 2011) and the growing body of evidences suggest that the number is steadily increasing. So there is an urgent need to clean-up the contaminated soils for maintaining their homeostasis. For example, European Environmental Agency (EEA) has estimated that there are 3 million contaminated sites in Europe, out of which, around 250,000 sites are highly contaminated and need immediate remediation (EEA, 2007; Gillespie and Philp, 2013). Moreover, by 2050, the number of contaminated sites needing remediation may increased by $>50 \%$ 
Table 1

List of common and emerging pollutants.

\begin{tabular}{|c|c|}
\hline Type of pollutants & Examples \\
\hline Metals and metalloids & As, $\mathrm{Ni}, \mathrm{Cd}, \mathrm{Hg}, \mathrm{Pb}, \mathrm{Mn}, \mathrm{Cr}, \mathrm{Mg}$ etc. \\
\hline $\begin{array}{l}\text { Persistent organic } \\
\text { pollutants }\end{array}$ & $\begin{array}{l}\text { Aldrin, chlordane, dieldrin, dioxins, endrin, endosulfans, heptachlor, mirex, toxaphane, chlordecone, HCB, } \alpha-, \beta-, \gamma-H_{C H} \text { PCB, DDT, PCDF, } \\
\text { PBDE, HBCD etc. }\end{array}$ \\
\hline Petroleum hydrocarbons & Hexane, benzene, toluene, xylenes, naphthalene etc. \\
\hline $\begin{array}{l}\text { Organophosphorus } \\
\text { pesticides }\end{array}$ & Chlorpyrifos, dichlorvos, dimethoate, malathion, parathion, parathion-methyl, phenthoate, phorate etc. \\
\hline Carbamate insecticides & Aldicarb, aminocarb, carbaryl, carbofuran, carbosulfan, fenoxycarb, methiocarb, methomyl etc. \\
\hline Herbicides & 2,4-D-, atrazine, simazine, glyphosate etc. \\
\hline Radionuclides & Uranium, thorium, plutonium, strontium, caesium etc. \\
\hline $\begin{array}{l}\text { New and emerging } \\
\text { pollutants }\end{array}$ & $\begin{array}{l}\text { Antibiotics, antiepileptics, analgesics, anti-inflammatories, lipid regulators, betablockers, diuretics, contrast media, cosmetics, psycho- } \\
\text { stimulants, disinfectant, antidepressants, plasticisers and phthalates, wood preservatives, paint additives etc. }\end{array}$ \\
\hline Nanoparticles & Carbon nanotubes, $\mathrm{TiO}_{2}, \mathrm{SiO}_{2}$, fullerenes, metal-phosphates, aluminosilicates, silver nanoparticles, $\mathrm{ZnO}$ nanoparticles etc. \\
\hline
\end{tabular}

(EEA, 2007). Although the remediation efforts are progressing, only 80000 have been successfully cleaned up in Europe during the last 30 years (Gillespie and Philp, 2013). Similarly, more than 66, 0000 sites are already demarked by the United States Environmental Protection Agency (US EPA, 2013) for multipurpose phytoremediation. However, there is no official documentation of the number of contaminated sites in developing countries. Although developed countries have suitable technological frameworks for the onsite clean-up of contaminated sites, no such efforts are available in developing countries and even they do not have such policies or any methodical frame works for the onsite remediation of contaminated sites (Doberl et al., 2013; Tripathi et al., 2014a,b). Therefore there is an urgent need to design suitable policy frame works based on green and clean technologies for the immediate remediation and management of contaminated soils in developing nations.

In this context, plant-based clean-up technologies (phytotechnologies) are gaining popularity as a clean and sustainable technology for the remediation of contaminated soils (Peuke and Rennenberg, 2005). Apart from the removal of pollutants from soils, phytoremediation also provides additional benefit such as soil quality improvement, soil carbon sequestration and phytobiomass for fiber, biomass and biofuel production (Abhilash et al., 2012). However, the successes of plant-based technologies are limited by many factors. For instance, phytoremediation often does not show the desired results when the polluted sites are cocontaminated with multiple pollutants. Similarly, phytoremediation is also governed by pollutant behaviour, microbial interactions, edpahic and climatic conditions. However, recent studies proved that changing climate will affect the plant-microbe interactions in the soil system. Furthermore, the warming climate may also alter the mobility, leaching, global transport, bioavailability, volatilization, fate and behaviour of the chemical pollutants present in the soil system (Lamon et al., 2009; Miraglia et al.,2009; Tripathi et al., 2015). Most importantly, there is a paucity of information regarding the indicators for assessing the sustainability of a remediated soil sites. Therefore, the present work is aimed to address three important challenges in plant-based clean-up technologies such as (i) the difficulties in remediation of soils contaminated with multiple pollutants (ii) the plant-microbepollutant and climate nexus and (iii) identifying key sustainability indicators for the remediation of contaminated soil system

\section{Phytoremediation of soils contaminated with multiple pollutants}

Several microbial and plant species are being tested for the remediation of the soil pollutants (Macek et al., 2000; Chiang et al., 2006; Glick 2010; Abhilash et al., 2009; Abhilash et al., 2013a,b; Kcil et al., 2015). However, the success of any phytoremediation technology depends upon the three important factors such as (i) inherent nature of the plant species (ii) microflora present in the soil and (iii) physico-chemical properties of the pollutant itself (Fig. 1.) Globally, most of the soils are either contaminated with organic or inorganic pollutants or a mixture of both (Wang et al., 2010 ). According to USEPA, more than $67 \%$ of the polluted sites are co-contaminated with heavy metals and organic pollutants (USEPA, 2004). As a result, the remediation of the soils contaminated with mixed pollutants is a difficult task as the organic and inorganic compounds differ in their properties and

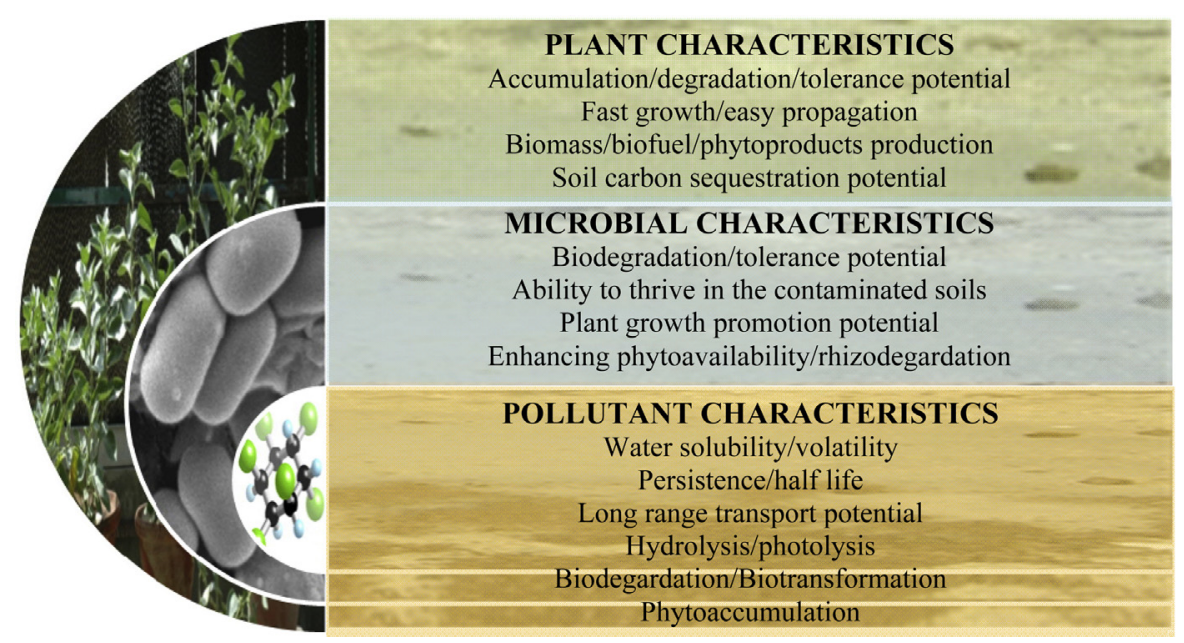

Fig. 1. Plant-microbe-pollutant nexus play a key role in the phytoremediation of contaminated soils. 
behaviours in the soil system (Wang et al., 2010; Cang et al., 2013; Lesley and Colette, 2013). This is a serious issue of global concern as many of the sites are co-contaminated with wide nature of pollutants (Lesley and Colette, 2013). Heavy metals, petroleum hydrocarbons, pesticides, organic solvents, wood preservatives, flame retardants, nanoparticles etc are the key component of the multiple pollutants contaminating the soil system. Hence the clean-up of the soils co-contaminated with multiple pollutants is a difficult task as the uptake, accumulation, phytodegradation, translocation and cellular sequestration processes differ for each group of pollutants (Sandrin and Maier, 2003; Abhilash et al., 2012). Moreover, the physicochemical properties of the heavy metals and organic pollutants contrast in nature. For instance, heavy metals are mostly either water or acid soluble thus they easily migrate through the soil and integrate with Fe-Mn and soil organic matter. However, the organic pollutants integrate with the soil organic matter due to their higher hydrophobicity (Cang et al., 2013). Although various microorganisms are capable for the complete mineralization of various organic pollutants, the cocontamination with heavy metals often suppresses the microbial activity and their subsequent degradation in soil (Lu and Zhang, 2014) due to the synergistic toxicity of heavy metals and organic pollutants (Dong et al., 2013). On the other side, heavy metals are resistant to microbial degradation process (Bolan et al., 2014). They are mostly remediated through the help of hyperaccumulator plants (Peer et al., 2005). However, the toxicity of the organic pollutants may reduce the survival and phytoremediation potential of such hyper accumulators in a heavy metal-organic pollutant co-contaminated soil system. Therefore, it is imperative to identify new candidate species of plants and microbes for the remediation of soil system contaminated with mixed pollutants and develop innovative ways for reducing the toxicity of mixed pollutants to remediator species.

\section{Plant-microbe-pollutants and climate nexus}

As we discussed earlier, the success of a phytoremediation technique mainly depends upon the plant-microbe-pollutant interactions. However, it is commonly believed that climate change will have direct or indirect effects on plant-microbepollutant interactions which in turn affect the phyto/ bioremediation of pollutants (Abhilash et al., 2013a,b). For example, the elevated $\mathrm{CO}_{2}$ will enhance the plant productivity due to the increase in photosynthetic rate (Ma et al., 2012; Abhilash et al., 2015). As a result, it will lead to the enhanced root exudation and microbial activity in the rhizosphere (Zheng et al., 2008; Phillips et al., 2009; Abhilash and Dubey, 2014) mainly due to the increased photosynthate allocation to the root system. It has been generally perceived that an increase in root exudation might enhance the availability of the pollutants for phytouptake and microbial degradation due to the decrease in soil $\mathrm{pH}$ and an increase in dissolved organic matter content (Kim and Kang, 2010) in the rhizospheric system. Apart from this, the climate change can also affect the microbial composition and structure of the soil ( $\mathrm{Wu}$ et al., 2009; Castro et al., 2009) due to the alteration in soil biochemistry. Hence, the change in microbial community structure will also affect the rhizospheric processes supporting the phytoremediation of the pollutants (Fig. 2). Moreover, as discussed in the section 2 , it is also evidenced that climate change can alter the fate, behaviour, mobility, leaching, global transport, bioavailability and volatilization of the chemical pollutants (Lamon et al., 2009; Mrigalia et al., 2009). Furthermore, it is speculated that the rise in temperature will reduce the phytoremediation potential of plants by limiting the availability of the pollutants to plants for uptake and accumulation. However, still it is unclear that how changing climate will affect the plant-microbe-pollutant interactions and phytoremediation of mixed pollutants. Therefore, more studies are essential to understand the plant-microbepollutant nexus under changing climatic conditions.

\section{The sustainability indicators for the remediated soils}

Defining benchmarks for evaluating the performance of a plantbased clean-up technology is another important challenge regarding the onsite remediation of polluted soils. Currently most of the remediation systems are solely targeted to the pollutant removal from the soil with less or no attention to the sustainability components such as soil biology, biodiversity and biochemistry (Tripathi el al., 2014a,b). Moreover, no emphasis is given to the carbon emission and socioeconomic component of the revitalized/ restored system. Therefore, in order to analyse the sustainability of the remediation process, suitable indicators should be framed and

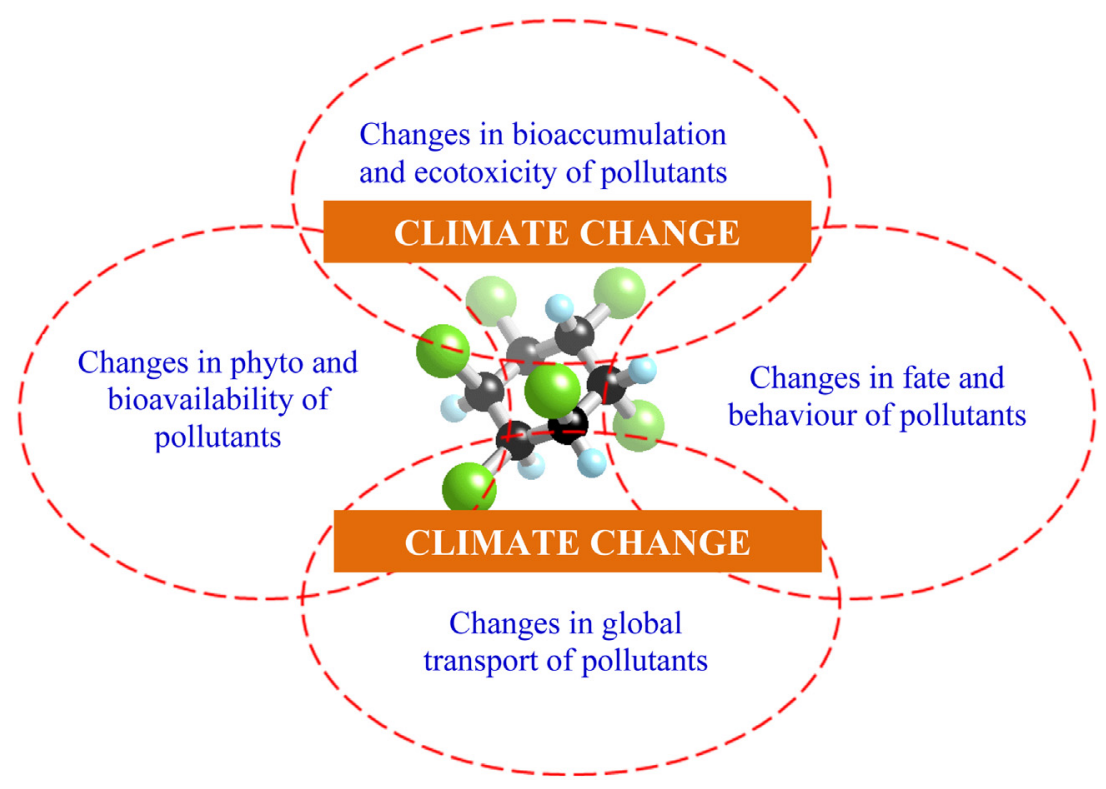

Fig. 2. Plausible effects of climate change on fate, behaviour and bioremediation of pollutants. 


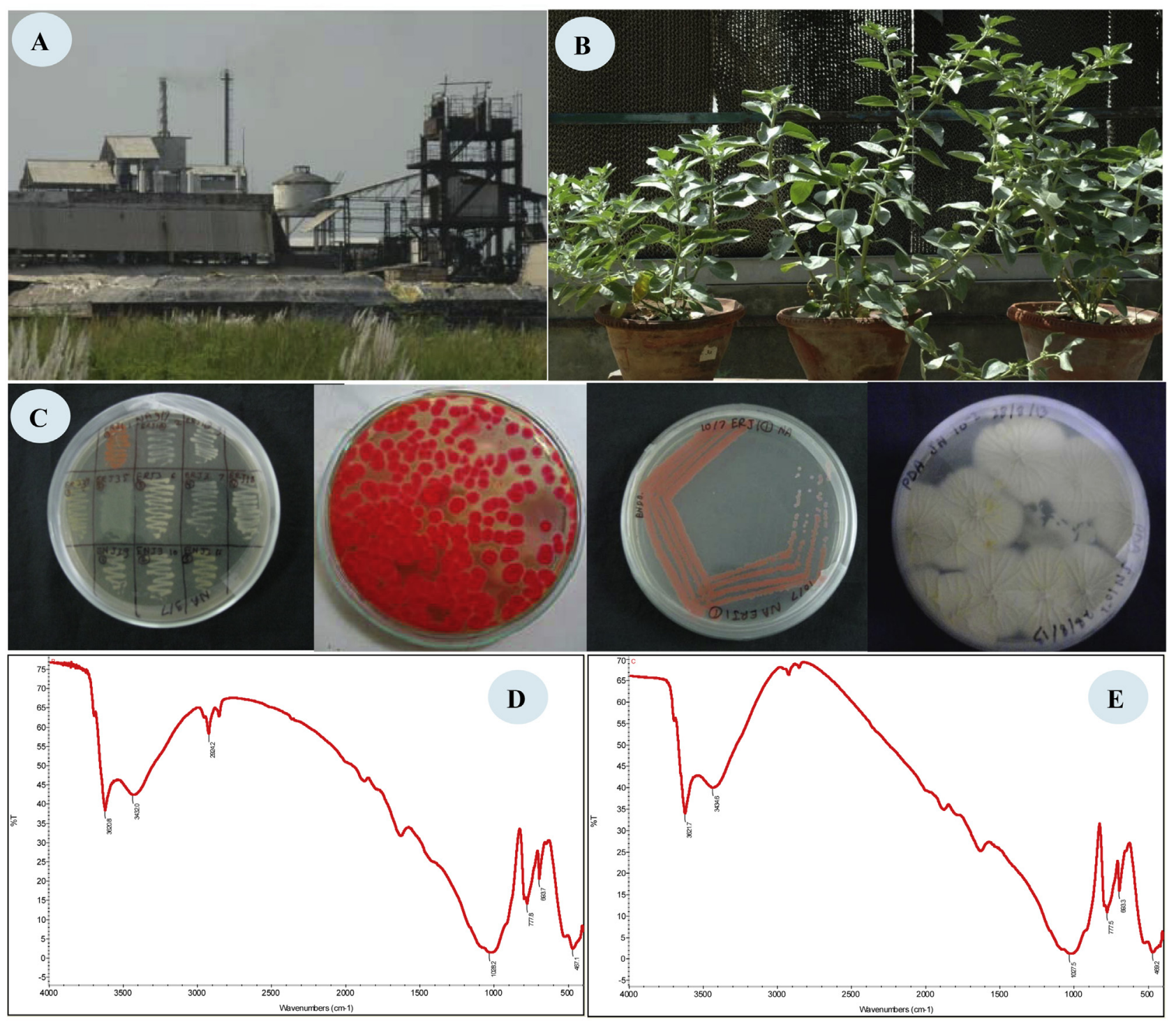

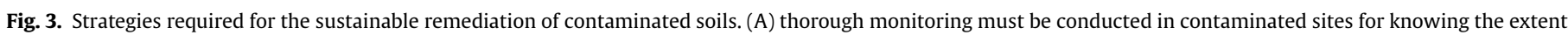

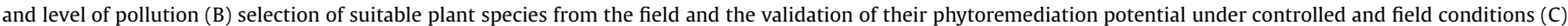

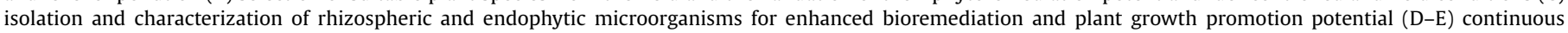
monitoring of the soil quality (before and after the phytoremediation).

Table 2

Sustainability indicators for evaluating the performance of the remediated soil system.

\begin{tabular}{|c|c|}
\hline $\begin{array}{l}\text { Sustainability } \\
\text { component }\end{array}$ & Indicators \\
\hline $\begin{array}{l}\text { Clean-up potential } \\
\text { Soil quality }\end{array}$ & $\begin{array}{l}\text { Pollutant removal, residual concentration in soil, metabolites, end products. } \\
\text { pH, EC, soil moisture, soil texture, water holding capacity, bulk density, particle density, porosity, permeability, aggregate stability, soil organic } \\
\text { matter, cation exchange capacity, sodium, potassium, calcium, nitrogen, phosphorous, soil enzymes. }\end{array}$ \\
\hline Soil microorganisms & Microbial diversity, functional diversity, microbial biomass carbon, catabolic genes. \\
\hline Biodiversity & Plant diversity, presence of ecological indicators/sensitive species like earthworms, honeybees, butterflies, lichens. \\
\hline Groundwater quality & $\mathrm{pH}, \mathrm{EC}$, nutrients, pollutant level \\
\hline Carbon emission & Total carbon emission, total carbon in standing biomass, soil carbon sequestration. \\
\hline Bioeconomy & Phytobiomass for timber, biofuel, bioethanol and fiber. \\
\hline Social aspects & Stake holder involvement, job opportunities, community participation and entrepreneurial opportunities. \\
\hline
\end{tabular}

validated periodically (Fig. 3 ). As detailed in Table 2, the following sustainability components must be considered such as (i) pollutant level/residual concentration after the phytoremediation process (ii) key variables depicting the improvement of the physicochemical properties of soil (iii) the enrichment of microbial biomass and their functional diversity in soil (iv) the positive changes in biodiversity component including the sensitive and key indicator species after the remediation process (vi) positive changes in the improvement of groundwater quality (vi) the carbon emission/accounting during the each and every step of the remediation process (vii) stocktaking of potential phytoproducts for biobased economy and entrepreneurial activities and most 
importantly (viii) the social aspects including the social acceptability of the remediation process. All of these components/ indicators should be taken together for evaluating the sustainability certification of the clean-up program. Most importantly, the social acceptance of the remediation process should be assessed by the level of stakeholder involvement/community participation, whereas the economic feasibility can be judged by the costeffectiveness of the overall remediation process. Importantly, the feasibility for obtaining pollutant free phytoproducts for bio-based entrepreneurial (Gillespie and Philp, 2013) activities should also be assessed in detail.

\section{Conclusions and future perspectives}

Although the remediation of soils contaminated with multiple pollutants is difficult and will be more challenging under changing climate, recent advances in omics technologies may provide ample solution to alter the traits of plant and microbe for accumulation and degradation of heavy metals and organic pollutants. Various proteomic, metabolomic, genomic, metagenomic and transcriptomic approaches could exploited for identifying the desirable traits that could maximize the benefits of field remediation technologies. Suitable plants could be engineered for enhancing their biomass production and rhizosecretions and thereby increasing the phytouptake of the pollutants and also the microbial activity in the rhizosphere which in turn enhance the degradation of organic pollutants and the phytouptake of heavy metals. For example, with the advent of next generation sequencing technologies like single cell genomics, ultra-fast pyrosequencing technologies, it would be possible to screen large number of metagenomes in a very short time span for identifying novel microbes, pathways, operons and catabolic genes for designing customized microbes and transgenic plants for the sustainable remediation of soils contaminated with multiple pollutants and also for conferring improved traits in selected plants and microbes for their easy growth and establishment in contaminated soil.

Thus it is imperative to develop novel and customized strategies for remediation of soils contaminated with multiple pollutants under changing climate. Therefore, future research priorities should be given due consideration for studying the plantmicrobe-pollutant nexus under changing climatic conditions. Moreover, as we suggested earlier, it is very essential to study the effect of changing climate especially the global warming on plant-microbe-pollutant interactions and microbial-assisted phytoremediation of soils contaminated with mixed/multiple pollutants.

\section{Acknowledgements}

Financial support from Science Engineering Research Board, Govt. of India (No. SR/FT/LS-111/2011), is gratefully acknowledged. P.C. Abhilash and Leonardo F. Fraceto would like to thank the visiting fellowship from grant \#2014-26873-3, São Paulo Research Foundation (FAPESP).

\section{References}

Abhilash, P.C., Dubey, R.K., 2014. Integrating aboveground-belowground responses to climate change. Curr. Sci. 1637-1638 12.

Abhilash, P.C., Tripathi, V., Dubey, R.K., Edrisi, S.A., 2015. Coping with changes: adaptation of trees in a changing environment. Trends Plant Sci. 20, 137-138.

Abhilash, P.C., Powell, J., Singh, H.B., Singh, B., 2012. Plant-microbe interactions: novel applications for exploitation in multipurpose remediation technologies. Trends Biotechnol. 30, 416-420.

Abhilash, P.C., Dubey, R.K., Tripathi, V., Srivastava, P., Verma, J.P., Singh, H.B., 2013a. Remediation and management of POPs-contaminated soils in a warming climate: challenges and perspectives. Environ. Sci. Pollut. Res. 20, 5879-5885.
Abhilash, P.C., Dubey, R.K., Tripathi, V., Srivastava, P., Verma, J.P., Singh, H.B., 2013b. Adaptive soil management. Curr. Sci. 104, 1275-1276.

Abhilash, P.C., Singh, N., 2009. Pesticide use and application: an Indian scenario. J. Hazard. Mater. 165, 1-12.

Bakshi, M., Singh, H.B., Abhilash, P.C., 2014. The unseen impact of nanoparticles: more or less? Curr. Sci. 106 (3), 350-352.

Bolan, N., Kunhikrishnan, A., Thangarajan, R., Kumpiene, J., Park, J., Makino, T., Kirkham, M.B., Scheckel, K., 2014. Remediation of heavy metal(loid) s contaminated soils -To mobilize or to immobilize? J. Hazard. Mater. 266, $141-$ 166.

Cang, L., Fan, G.P., Zhou, D.M., Wang, O.W., 2013. Enhanced-electrokinetic remediation of copper-pyrene co-contaminated soil with different oxidants and $\mathrm{pH}$ control. Chemosphere 90, 2326-2331.

Castro, H.F., Classen, A.T., Austin, E.E., Norby Schadt, R.J.C.W., 2009. Soil microbial community responses to multiple experimental climate change drivers. Appl. Environ. Microbiol. 76 (4), 999-1007 2010.

Chiang, P.N., Wang, M.K.K., Chiu, C.Y., Chou, S.Y., 2006. Effects of cadmium amendments on low-molecular-weight organic acid exudates in rhizosphere soils of tobacco and sunflower. Environ. Toxicol. 21, 479-488.

de Oliveira, J.L., Campos, E.V.R., Bakshi, M., Abhilash, P.C., Fraceto, L.F., 2014. Application of nanotechnology for the encapsulation of botanical insecticides for sustainable agriculture: prospects and promises. Biotechnol. Adv. 32, 15501561.

Doberl, G., Ortmann, M., Fruhwirth, W., 2013. Introducing a goal-oriented sustainability assessment method to support decision making in contaminated site management. Environ. Sci. Policy 25, 207-217.

Dong, Z.Y., Huang, W.H., Xing, D.F., Zhang, H.F., 2013. Remediation of soil cocontaminated with petroleum and heavy metals by the integration of electrokinetics and biostimulation. J. Hazard. Mater. 260, 399-408.

Dubey, R.K., Tripathi, V., Singh, N., Abhilash, P.C., 2014. Phytoextraction and dissipation of lindane by Spinacia oleracea L. Ecotoxicol. Environ. Safety 109, 22 26.

FAO, 2011. The state of the world's land and water resources for food and agriculture managing systems at risk., FAO Rome. 2011

Gavrilescu, M., Demnerová, K., Aamand, J., Agathos, S., Fava, F., 2015. Emerging pollutants in the environment: present and future challenges in biomonitoring, ecological risks and bioremediation. New Biotechnol. 32, 147-156.

Gillespie, I.M., Philp, J.C., 2013. Bioremediation, an environmental remediation technology for the bioeconomy. Trends Biotechnol. 31 (6), 329-332.

Glick, B.R., 2010. Using soil bacteria to facilitate phytoremediation. Biotechnol. Adv. 28, 367-374.

Jamil, S., Abhilash, P.C., Singh, N., Sharma, P.N., 2009a. Jatropha curcas: a potential crop for phytoremediation of coal fly ash. J. Hazard. Mater. 172, 269-275.

Jamil, S., Abhilash, P.C., Singh, A., Singh, N., Behl, H.M., 2009b. Flyash trapping and metal accumulating capacity of plants: implication for green belt around thermal power plants. Landscape Urban Plann. 92, 136-147.

Kim, S., Kang, H., 2010. Effects of elevated CO2 and Pb on phytoextraction and enzyme activity. Water Air Soil Pollut. 219, 365-375 2011.

Kcil, A., Erust, C., Ozdemiroglu, S., Fonti, V., Beolchini, F., 2015. A review of approaches and techniques used in aquatic contaminated sediments: metal removal and stabilization by chemical and biotechnological processes. J. Cleaner Prod. doi:http://dx.doi.org/10.1016/j.jclepro.2014.08.009 2014. . J.

Lamon, L., Valle, M.D., Critto, A., Marcomini, A., 2009. Introducing an integrated climate change perspective in POPs modelling and regulation. Environ. Pollut. 157, 1971-1980.

Lesley, C.B., Colette, D., 2013. The potential use of phytoremediation for sites with mixed organic and inorganic contamination. Crit. Rev. Environ. Sci. Technol. 43, 217-259.

Lu, M., Zhang, Z.Z., 2014. Phytoremediation of soil co-contaminated with heavy metals and deca-BDE by co-planting of Sedum alfredii with tall fescue associated with Bacillus cereus JP12. Plant Soil 382, 89-102.

Ma, L., Huang, W., Guo, C., Wang, R., Xiao, C., 2012. Soil microbial properties and plant growth responses to carbon and water addition in a temperate steppe: the importance of nutrient availability. PLoS One 7 (4) e35165.

Miraglia, M., Marvin, H.J., Kleter, G.A., Battilani, P., Brera, C., Coni, E., 2009. Climate change and food safety: an emerging issue with special focus on Europe. Food Chem. Toxicol. 47, 1009-1021.

Peer, W.A., Baxter, I.R., Richards, E.L., Freeman, J.L., Murphy, A.S., 2005. Phytoremediation and hyperaccumulator plants. Topics in current genetics. In: Tamás, M.J., Martinoia, E. (Eds.), Molecular Biology of Metal Homeostasis and Detoxification, 14. , pp. 299-340.

Peuke, A.D., Rennenberg, H., 2005. Phytoremediation. EMBO Reports 6 (6), 497-501.

Phillips, R.P., Bernhardt, E.S., Schlesinger, W.H., 2009. Elevated $\mathrm{CO}_{2}$ increases root exudation from loblolly pine (Pinus taeda) seedlings as an N-mediated response. Tree Physiol. 29, 1513-1523 2009.

Sandrin, T.R., Maier, R.M., 2003. Impact of metals on the biodegradation of organic pollutants. Environ. Health Perspect. 111, 1093-1101.

Srivastava, S., Verma, P.C., Chaudhry, V., Singh, N., Abhilash, P.C., Kumar, K.V., Sharma, N., Singh, N., 2013. Influence of inoculation of arsenic-resistant Staphylococcus arlettae on growth and arsenic uptake in Brassica juncea (L.) Czern. Var R46. J. Hazard. Mater. 262, 1039-1047.

Srivastava, M., Abhilash, P.C., Singh, N., 2011. Remediation of Lindane using engineered nanoparticles. J. Biomed. Nanotechnol. 7 173-175.

Macek, T., Macková, M., Kás, J., 2000. Exploitation of plants for the removal of organics in environmental remediation. Biotechnol. Adv. 18, 23-34. 
Tripathi, V., Dubey, R.K., Edrisi, S.A., Narain, K., Singh, H.B., Singh, N., Abhilash, P.C. 2014a. Towards the ecological profiling of a pesticide contaminated soil site for remediation and management. Ecol. Eng. 71, 318-325.

Tripathi, V., Dubey, R.K., Singh, N., Singh, H.B., Abhilash, P.C., 2014b. Is Vigna radiata is suitable for cropping in lindane contaminated soil. Ecol. Eng. 73, 219-223.

Tripathi, V., Abhilash, P.C., Singh, H.B., Patra, D.D., Singh, N., 2015. Effect of temperature variation on lindane dissipation and microbial activity in soil. Ecol. Eng. 79, 54-59 s.

USEPA, Cleaning Up the nation's waste sites: markets and technology trends. Office of solid waste and emergency response, Washington DC. 2004; 3-9

Vijgen, J., Abhilash, P.C., Li, Y.F., Lal, R., Forter, M., Torres Singh, J., Yunus, M., Tian, C. Schäffer, A., Weber, R., 2011. HCH isomers as new Stockholm Convention POPs-A global perspectives on the management of Lindane and its waste isomers. Environ. Sci. Pollut. Res. 18, 152-162.

Wang, G., Zhou, Y., Wang, X., Chai, X., Huang, L., Deng, N., 2010. Simultaneous removal of phenanthrene and lead from artificially contaminated soils with glycine-cyclodextrin. J Hazard Mat. 184, 690-695.

Wu, H., Tang, S., Zhang, X., Guo, J., Song, Z., Tian, S., 2009. Using elevated $\mathrm{CO}_{2}$ to increase the biomass of a Sorghum vulgare $\times$ Sorghum vulgare var. sudanense hybrid and Trifolium pratense L. and to trigger hyperaccumulation of cesium. J. Hazard. Mater. 170, 861-870.

Zheng, J., Wang, H., Li, Z., Tang, S., Chen, Z., 2008. Using elevated carbon dioxide to enhance copper accumulation in Pteridium revolutum, a copper-tolerant plant, under experimental conditions. Int. J. Phytorem. 10, 161-172. 